\title{
ХИМИЧЕСКИЕ НАУКИ
}

\section{SYNTHESIS OF VINYL ESTER OF LACTIC ACID}

Parmanov A.B.

Doctorate of 3-course of the Faculty of chemistry of the National University of Uzbekistan

Nurmonov S.E.

Doctor of technical sciences, professor, Faculty of chemistry of the National University of Uzbekistan

Abdugafurov I.A.

Doctor of chemical sciences, professor

Faculty of Chemistry of the National University of Uzbekistan

Ziyadullaev O.E.

Doctor of chemical sciences, professor,

Vice Rector by research Chirchik work State Pedagogical Institute

Mirkhamitova D.X.

Doctor of chemical sciences, Faculty of Chemistry of the National University of Uzbekistan DOI: $10.31618 /$ ESU.2413-9335.2019.2.64.227

\section{ABSTRACT}

In this work vinyl ester of lactic acid by homogeneous catalytic vinylation of lactic acid with acetylene was synthesized. The influence of temperature, nature of catalysts and the reaction time on the product yield was studied. The process was carried out at a temperature of $80-140{ }^{\circ} \mathrm{C}$ for 2 hours by passing acetylene through solution of lactic acid in the DMFA catalyst system. As a catalyst Lewis acids $\left(\mathrm{ZnCl}_{2}, \mathrm{AlCl}_{3}, \mathrm{FeCl}_{3}, \mathrm{AlCl}_{3}\right.$ and $\mathrm{AlCl}_{3} \cdot 6 \mathrm{H}_{2} \mathrm{O}$ ) $10 \%$ by weight of lactic acid were used.

\section{АННОТАЦИЯ}

В работе синтезирован виниловый эфир молочной кислоты гомогенного-каталитическим винилированием молочной кислоты ацетиленом. Изучено влияние температуры, природы катализатора и длительности реакции на выход продукта. Процесс проводили при температуре $80-140{ }^{\circ} \mathrm{C}$ в течение 2 часов пропусканием ацетилена через раствора молочной кислоты в системе DMFA-катализатор. В качестве катализатора использовались Льюисовые кислоты $\left(\mathrm{ZnCl}_{2}, \mathrm{CrCl}_{3}, \mathrm{FeCl}_{3}, \mathrm{AlCl}_{3}\right.$ и $\left.\mathrm{AlCl}_{3} \bullet 6 \mathrm{H}_{2} \mathrm{O}\right) 10 \%$ от массы молочной кислоты.

Key words: Lactic acid, acetylene, zinc acetate, Lewis acids, vinylation, vinyl ester of lactic acid.

Ключевые слова: Молочная кислота, ацетилен, ацетат цинка, Льюисовые кислоты, винилирование, виниловый эфир молочной кислоты.

\section{Introduction}

Currently various biologically active organic compounds with unique properties are synthesized in the oil and gas industry using modern innovative technologies. On an industrial scale acetylene is obtained by pyrolysis of methane, vinyl acetate production is based on vinylation of acetic acid by acetylene one of the most important raw materials in the chemical industry [1-3].

Many compounds with different properties are synthesized on the basis of carboxylic acids and are widely used in variou fields of industry. In particular, their vinyl esters are used as solvents and in the food industry as flavorings; monomers in the preparation of polymers and as lubricants in the preparation of various materials [4]. In this direction acetic acid is sufficiently studied and produced in industrial scale. But the reaction of vinylation of compounds contained simultaneously in their molecules hydroxyl and carboxyl groups by acetylene has not been studied. There are several ways of obtain vinyl esters, among them the most technologically and cost-effective is catalytic vinylation of some organic acids in homogeneous and heterogeneous conditions [5].
2-Hydroxypropionic acid (lactic acid- $\mathrm{CH}_{3}-$ $\mathrm{CH}(\mathrm{OH})-\mathrm{COOH})$ is a natural, widespread substance, wich can be obtained by fermentation or chemical synthesis [6]. It's production is 40,000 tons per year and it is widely used as a food product, plant growth regulator, environmentally friendly "green" solvent, biodegradable polymers and special chemical intermediate [7]. Currently lactic acid and it's polymers are produced globally by large American companies such as Cargill, Ecochem and Archer Daniels Midland [8].

In this paper, the process of vinylation of lactic acid by homogeneous catalytic method was investigated. The influence of the catalyst nature, temperature and duration on the reaction on it's processing and yield of product has been investigated.

\section{EXPERIMENTAL}

Synthesis of vinyl ester of lactic acid. In four-neck flask by volume of $200 \mathrm{ml}$, equipped with a fridge, thermometer, tube for introduction of acetylene and mixer $100 \mathrm{ml}$ of the solvent dimethylformamide (DMFA); $1.8 \mathrm{~g}(0.2 \mathrm{~mol})$ of lactic acid; $0.18 \mathrm{~g}$ of zinc acetate $(10 \%$ by mass of lactic acid) and $0.018 \mathrm{~g}$ 
$\mathrm{AlCl}_{3} \cdot 6 \mathrm{H}_{2} \mathrm{O}$ ( $10 \%$ by mass of zinc acetate) have been playced.

The reaction mixture was heated in a thermostat to temperature $80{ }^{\circ} \mathrm{C}$. Acetylene was introduced through a tube with constant stirring. The acetylene feed rate was controlled via a foam flowmeter. Two hours later the reaction was stopped and after cooling the reaction mixture was distilled in a vacuum $(10-15 \mathrm{~mm} \mathrm{Hg}$. C.) in the presence of $0.002 \mathrm{~g}$ of hydroquinone (inhibitor) at this vinyl ester of lactic acid was obtained $1.32 \mathrm{~g}$ (57\% yield) with boiling point $83-85^{\circ} \mathrm{C}$. Reaction was carried out by this method at different durations and temperatures. Zinc acetate+Lewis acid: $\mathrm{ZnCl}_{2}, \mathrm{AlCl}_{3}$, $\mathrm{FeCl}_{3}, \mathrm{AlCl}_{3}$ and $\mathrm{AlCl}_{3} \bullet 6 \mathrm{H}_{2} \mathrm{O}$ were used as catalysts.

\section{RESULTS AND DISCUSSION}

Vinylation of lactic acid by homogeneouscatalytic method was work carried out. The influence of the catalyst nature and temperature on the process was studied. The reaction was carried out in a dimethylformamide (DMF) solution in the presence of catalysts: zinc acetate and $10 \%$ Lewis acids $\mathrm{ZnCl}_{2}$, $\mathrm{AlCl}_{3}, \mathrm{FeCl}_{3}, \mathrm{AlCl}_{3}$ and $\mathrm{AlCl}_{3} \cdot 6 \mathrm{H}_{2} \mathrm{O}$ relative to it's mass. The process was carried out at a temperature of $80-140{ }^{\circ} \mathrm{C}$ for 2 hours in the DMFA catalyst system by passing acetylene through the reaction mass. The reaction scheme is as follows:<smiles>C=COC(=O)C(O)CCCCCCCC</smiles>

The process was processed with formation of $\pi$-complex between acetylene and zinc acetate:

$$
\begin{aligned}
& \mathrm{HC} \equiv \mathrm{CH}+\mathrm{Zn}\left(\mathrm{CH}_{3} \mathrm{COO}\right)_{2} \longrightarrow \mathrm{HC} \equiv \mathrm{CH} \\
& \stackrel{\mathrm{Zn}}{+2}\left(\mathrm{CH}_{3} \mathrm{COO}\right)_{2}
\end{aligned}
$$

-the in the result of rupture in it of one $\pi$ - bond, the $\delta$ - complex and anion of acetic acid were formed:

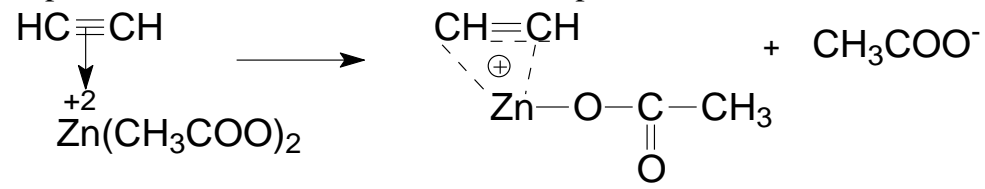

Due to the high electron density of carbonyl oxygen it becomes partially negative charged:<smiles>CC(O)C(=O)O</smiles>

Acetoacetic vinyl cation by acid anion interacts and forms an intermediate carbocation:

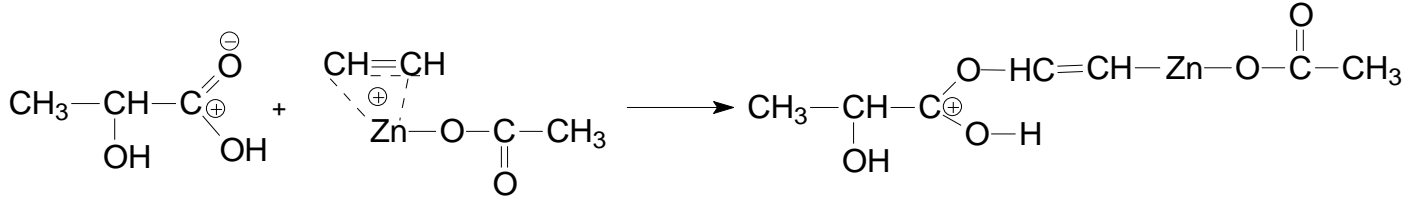

Wich has been regrouped with the decomposition and formation of vinyl ester of lactic acid:

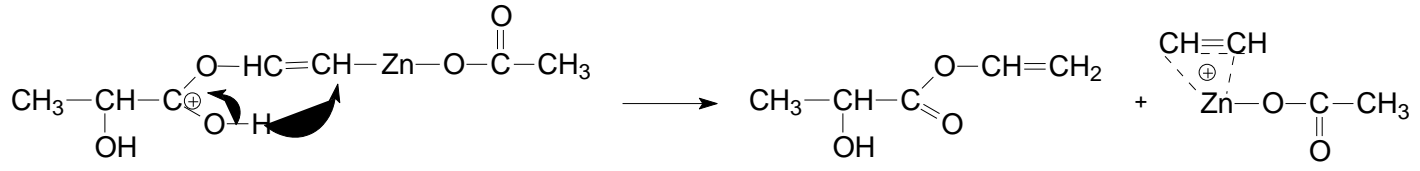

The structure of the obtained vinyl ester of lactic acid was proved by analysis of FTIR, ${ }^{1} \mathrm{H} \_\mathrm{NMR}$, ${ }^{13} \mathrm{C} \_$NMR spectras.

In the FT-IR spectrum of vinyl ester (Fig.1) alarms related to $\mathrm{C}=\mathrm{O}$ group was observed at $1755 \mathrm{~cm}^{-1}$, and $1206-1294 \mathrm{~cm}^{-1}$ - stretching vibrations inherent With the-C-O-C With the band at $1432 \mathrm{~cm}^{-1} \mathrm{CH}_{3}$ stretching vibrations, bands at $873 \mathrm{~cm}^{-1}$ deformation vibrations of $\mathrm{CH}_{2}$, a band at $1370 \mathrm{~cm}^{-1}$ stretching vibrations group $=\mathrm{CH}$, in $1132 \mathrm{~cm}^{-1}$ stretching vibrations $\mathrm{C}-\mathrm{OH}$ group $1646.14 \mathrm{~cm}^{-1}$ were observed manifestation of stretching vibrations, characteristic for the vinyl group ($\mathrm{CH}=\mathrm{CH}_{2}$ ). 


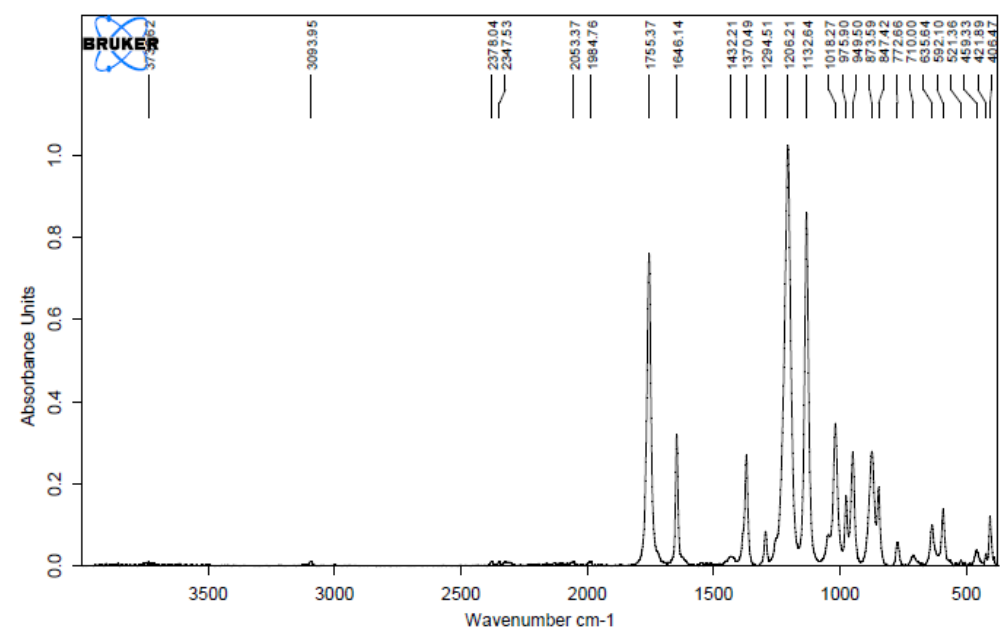

Figure 1. FT-IR spectrum of vinyl ester of lactic acid

In the ${ }^{1} \mathrm{H} \_N M R$ spectrum of vinyl ester of lactic acid (Fig.2) proton $(\mathrm{CH}=)$ vinyl group observed at 7.22 ppm., protons $\mathrm{CH}_{2}=$ at $4.8-4.5 \mathrm{ppm}$, hydrogen atom
$\mathrm{CH}$ group at 4.323 ppm., protons of methyl group $\left(\mathrm{CH}_{3}\right)$ at 2.03 ppm. were observed.

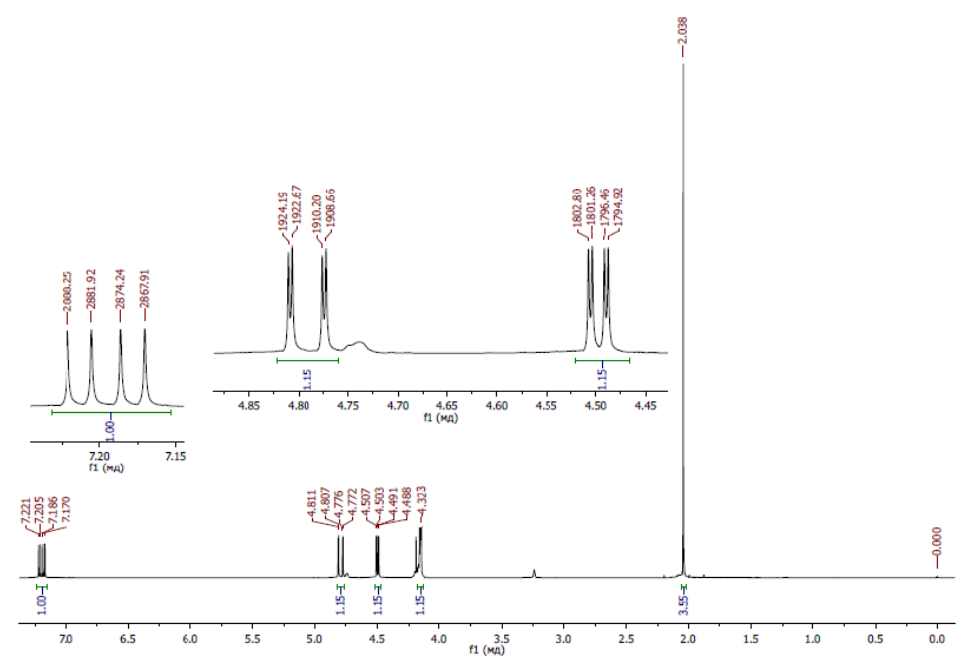

Figure 2. ${ }^{1} H_{-} N M R$-spectrum of vinyl ester of lactic acid

In the spectrum of ${ }^{13} C_{-}$NMR (Fig. 3) vinyl ester of lactic acid carbon atom of carboxylic group was observed at 169.4 ppm., carbon atom of $\mathrm{CH}-\mathrm{OH}$ group was observed at $67 \mathrm{ppm}$, carbon atoms of methyl and vinyl group $(\mathrm{CH}=)$ were observed at $20.5 \mathrm{ppm}$. and 142.4 ppm., carbon of $\mathrm{CH}_{2}=$ group was observed at $97.8 \mathrm{ppm}$.

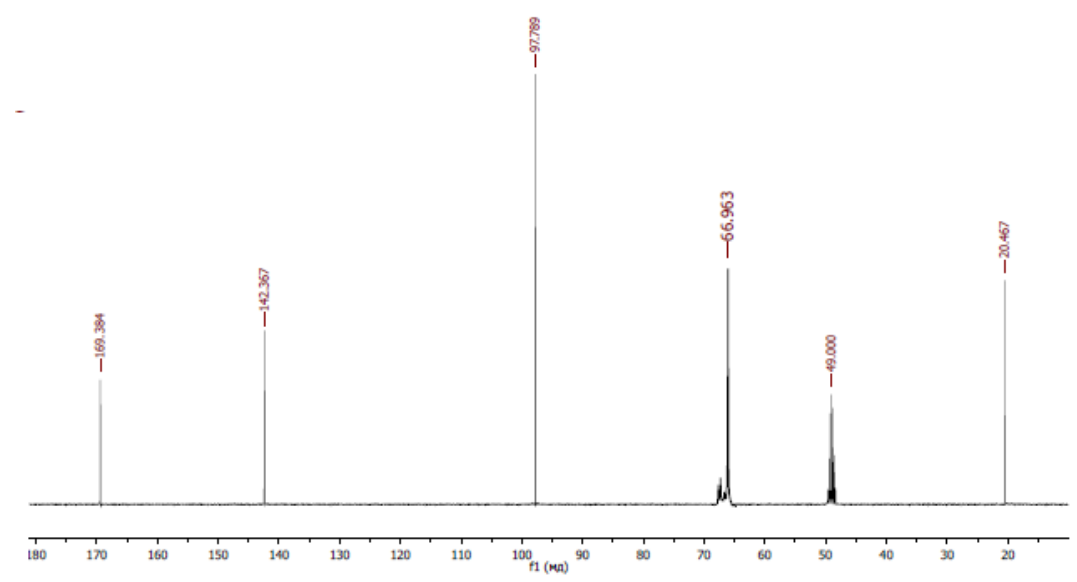

Figure 3. ${ }^{13}$ 
C_NMR - spectrum of vinyl ester of lactic acid

Some physical and chemical constants of the synthesized vinyl ester of lactic acid were determined (Table. 1).

Table 1

SOME PHYSICAL CONSTANTS OF THE VINYL ESTER OF LACTIC ACID

\begin{tabular}{|c|c|c|c|}
\hline Vinyl ester & $\mathrm{T}_{\text {b.p. }}{ }^{\circ} \mathrm{C}$ & $d_{4}^{20}$ & $n_{D}^{20}$ \\
\hline $\mathrm{CH}_{3}-\underset{\substack{\mathrm{CH} \\
\mathrm{OH}}}{\mathrm{COOCH}=\mathrm{CH}_{2}}$ & $149-150$ & 1.0552 & 1.4132 \\
\hline
\end{tabular}

The influence of the catalyst nature and temperature on the yield of vinyl ester of lactic acid was investigated. The results are presented in table. 2 .

Table 2

INFLUENCE OF THE NATURE OF THE CATALYST AND TEMPERATURE ON THE PROCESS OF

VINYLATION OF LACTIC ACID (CATALYST 10\% ZINC ACETATE AND 10\% METAL CHLORIDE SALTS WITH RESPECT TO THE ACID MASS, TEMPERATURE $80^{\circ} \mathrm{C}$, DURATION 2 HOURS)

\begin{tabular}{|c|c|c|}
\hline Temperature, ${ }^{\circ} \mathrm{C}$ & Catalysts & $\begin{array}{c}\text { Yield of vinyl ester of lactic } \\
\text { acid, } \%\end{array}$ \\
\hline \multirow{5}{*}{80} & $\mathrm{Zn}\left(\mathrm{CH}_{3} \mathrm{COO}\right)_{2}+\mathrm{ZnCl}_{2}$ & 24 \\
\hline & $\mathrm{Zn}\left(\mathrm{CH}_{3} \mathrm{COO}\right)_{2}+\mathrm{CrCl}_{3}$ & 33 \\
\hline & $\mathrm{Zn}\left(\mathrm{CH}_{3} \mathrm{COO}\right)_{2}+\mathrm{FeCl}_{3}$ & 47 \\
\hline & $\mathrm{Zn}\left(\mathrm{CH}_{3} \mathrm{COO}\right)_{2}+\mathrm{AlCl}_{3}$ & 49 \\
\hline & $\mathrm{Zn}\left(\mathrm{CH}_{3} \mathrm{COO}\right)_{2}+\mathrm{AlCl}_{3} \cdot 6 \mathrm{H}_{2} \mathrm{O}$ & 57 \\
\hline \multirow{5}{*}{90} & $\mathrm{Zn}\left(\mathrm{CH}_{3} \mathrm{COO}\right)_{2}+\mathrm{ZnCl}_{2}$ & 29 \\
\hline & $\mathrm{Zn}\left(\mathrm{CH}_{3} \mathrm{COO}\right)_{2}+\mathrm{CrCl}_{3}$ & 39 \\
\hline & $\mathrm{Zn}\left(\mathrm{CH}_{3} \mathrm{COO}\right)_{2}+\mathrm{FeCl}_{3}$ & 55 \\
\hline & $\mathrm{Zn}\left(\mathrm{CH}_{3} \mathrm{COO}\right)_{2}+\mathrm{AlCl}_{3}$ & 49 \\
\hline & $\mathrm{Zn}\left(\mathrm{CH}_{3} \mathrm{COO}\right)_{2}+\mathrm{AlCl}_{3} \cdot 6 \mathrm{H}_{2} \mathrm{O}$ & 62 \\
\hline \multirow{5}{*}{100} & $\mathrm{Zn}\left(\mathrm{CH}_{3} \mathrm{COO}\right)_{2}+\mathrm{ZnCl}_{2}$ & 34 \\
\hline & $\mathrm{Zn}\left(\mathrm{CH}_{3} \mathrm{COO}\right)_{2}+\mathrm{CrCl}_{3}$ & 42 \\
\hline & $\mathrm{Zn}\left(\mathrm{CH}_{3} \mathrm{COO}\right)_{2}+\mathrm{FeCl}_{3}$ & 59 \\
\hline & $\mathrm{Zn}\left(\mathrm{CH}_{3} \mathrm{COO}\right)_{2}+\mathrm{AlCl}_{3}$ & 54 \\
\hline & $\mathrm{Zn}\left(\mathrm{CH}_{3} \mathrm{COO}\right)_{2}+\mathrm{AlCl}_{3} \cdot 6 \mathrm{H}_{2} \mathrm{O}$ & 66 \\
\hline \multirow{5}{*}{110} & $\mathrm{Zn}\left(\mathrm{CH}_{3} \mathrm{COO}\right)_{2}+\mathrm{ZnCl}_{2}$ & 38 \\
\hline & $\mathrm{Zn}\left(\mathrm{CH}_{3} \mathrm{COO}\right)_{2}+\mathrm{CrCl}_{3}$ & 47 \\
\hline & $\mathrm{Zn}\left(\mathrm{CH}_{3} \mathrm{COO}\right)_{2}+\mathrm{FeCl}_{3}$ & 64 \\
\hline & $\mathrm{Zn}\left(\mathrm{CH}_{3} \mathrm{COO}\right)_{2}+\mathrm{AlCl}_{3}$ & 61 \\
\hline & $\mathrm{Zn}\left(\mathrm{CH}_{3} \mathrm{COO}\right)_{2}+\mathrm{AlCl}_{3} \cdot 6 \mathrm{H}_{2} \mathrm{O}$ & 69 \\
\hline \multirow{5}{*}{120} & $\mathrm{Zn}\left(\mathrm{CH}_{3} \mathrm{COO}\right)_{2}+\mathrm{ZnCl}_{2}$ & 43 \\
\hline & $\mathrm{Zn}\left(\mathrm{CH}_{3} \mathrm{COO}\right)_{2}+\mathrm{CrCl}_{3}$ & 53 \\
\hline & $\mathrm{Zn}\left(\mathrm{CH}_{3} \mathrm{COO}\right)_{2}+\mathrm{FeCl}_{3}$ & 67 \\
\hline & $\mathrm{Zn}\left(\mathrm{CH}_{3} \mathrm{COO}\right)_{2}+\mathrm{AlCl}_{3}$ & 63 \\
\hline & $\mathrm{Zn}\left(\mathrm{CH}_{3} \mathrm{COO}\right)_{2}+\mathrm{AlCl}_{3} \cdot 6 \mathrm{H}_{2} \mathrm{O}$ & 75 \\
\hline \multirow{5}{*}{130} & $\mathrm{Zn}\left(\mathrm{CH}_{3} \mathrm{COO}\right)_{2}+\mathrm{ZnCl}_{2}$ & 39 \\
\hline & $\mathrm{Zn}\left(\mathrm{CH}_{3} \mathrm{COO}\right)_{2}+\mathrm{CrCl}_{3}$ & 46 \\
\hline & $\mathrm{Zn}\left(\mathrm{CH}_{3} \mathrm{COO}\right)_{2}+\mathrm{FeCl}_{3}$ & 56 \\
\hline & $\mathrm{Zn}\left(\mathrm{CH}_{3} \mathrm{COO}\right)_{2}+\mathrm{AlCl}_{3}$ & 54 \\
\hline & $\mathrm{Zn}\left(\mathrm{CH}_{3} \mathrm{COO}\right)_{2}+\mathrm{AlCl}_{3} \cdot 6 \mathrm{H}_{2} \mathrm{O}$ & 66 \\
\hline \multirow[t]{5}{*}{140} & $\mathrm{Zn}\left(\mathrm{CH}_{3} \mathrm{COO}\right)_{2}+\mathrm{ZnCl}_{2}$ & 36 \\
\hline & $\mathrm{Zn}\left(\mathrm{CH}_{3} \mathrm{COO}\right)_{2}+\mathrm{CrCl}_{3}$ & 40 \\
\hline & $\mathrm{Zn}\left(\mathrm{CH}_{3} \mathrm{COO}\right)_{2}+\mathrm{FeCl}_{3}$ & 49 \\
\hline & $\mathrm{Zn}\left(\mathrm{CH}_{3} \mathrm{COO}\right)_{2}+\mathrm{AlCl}_{3}$ & 42 \\
\hline & $\mathrm{Zn}\left(\mathrm{CH}_{3} \mathrm{COO}\right)_{2}+\mathrm{AlCl}_{3} \cdot 6 \mathrm{H}_{2} \mathrm{O}$ & 58 \\
\hline
\end{tabular}

Analysis of the results has shown that the temperature in the range of $80-140{ }^{\circ} \mathrm{C}$ has a great influence on the process of vinylation of lactic acid. In all cases the vinyl ester of lactic acid is formed and it's yield has depended on the composition of catalyst and temperature of process. In range of temperature 80 to $120{ }^{\circ} \mathrm{C}$ the product yield increases from 24 to $75 \%$, further increasing temperature leads it's decreasing. 
But along with the increasing in product yield, it was observed a slight decomposition of DMFA in the acetylene flow at temperature above $120^{\circ} \mathrm{C}$. Also, due to the vinyl group the formation of oligomeric compounds is observed, what has reduced the yield of the product. The optimal temperature of the process with the participation of $\mathrm{AlCl}_{3} \cdot 6 \mathrm{H}_{2} \mathrm{O}$ is $120{ }^{\circ} \mathrm{C}$. and at this yield of vinyl ester was equaled $75 \%$. Therefore further investigation were carried out at this temperature.

Analysis of the results of the study on the effect of the duration of the reaction on the formation of vinyl ester of lactic acid show has that with the increasing duration of the reaction, the product yield has increased. In the presence of the catalyst $\mathrm{AlCl}_{3} \cdot 6 \mathrm{H}_{2} \mathrm{O}$ vinyl ester yield with increasing reaction time in the range of 1-4 hours has increased from 54.0 to $86.8 \%$.

INFLUENCE OF THE CATALYST NATURE AND REACTION TIME ON THE YIELD OF VIN

Table 3 ESTER OF LACTIC ACID (TEMPERATURE $120^{\circ} \mathrm{C}$ )

\begin{tabular}{|c|c|c|}
\hline Catalyst & Time, h. & $\begin{array}{c}\text { Yield of vinyl ester of lactic } \\
\text { acid, } \%\end{array}$ \\
\hline \multirow{6}{*}{$\mathrm{Zn}\left(\mathrm{CH}_{3} \mathrm{COO}\right)_{2}+\mathrm{ZnCl}_{2}$} & 1 & 32,0 \\
\hline & 2 & 43,0 \\
\hline & 3 & 48,2 \\
\hline & 4 & 53,9 \\
\hline & 5 & 45,0 \\
\hline & 6 & 39,6 \\
\hline \multirow{6}{*}{$\mathrm{Zn}\left(\mathrm{CH}_{3} \mathrm{COO}\right)_{2}+\mathrm{CrCl}_{3}$} & 1 & 41,8 \\
\hline & 2 & 53,0 \\
\hline & 3 & 69,6 \\
\hline & 4 & 73,3 \\
\hline & 5 & 68,0 \\
\hline & 6 & 57,6 \\
\hline \multirow{6}{*}{$\mathrm{Zn}\left(\mathrm{CH}_{3} \mathrm{COO}\right)_{2}+\mathrm{FeCl}_{3}$} & 1 & 47,6 \\
\hline & 2 & 67,0 \\
\hline & 3 & 70,8 \\
\hline & 4 & 76,2 \\
\hline & 5 & 69,9 \\
\hline & 6 & 58,6 \\
\hline \multirow{6}{*}{$\mathrm{Zn}\left(\mathrm{CH}_{3} \mathrm{COO}\right)_{2}+\mathrm{AlCl}_{3}$} & 1 & 46,0 \\
\hline & 2 & 63,0 \\
\hline & 3 & 66,0 \\
\hline & 4 & 73,0 \\
\hline & 5 & 64,6 \\
\hline & 6 & 50,0 \\
\hline \multirow{6}{*}{$\mathrm{Zn}\left(\mathrm{CH}_{3} \mathrm{COO}\right)_{2}+\mathrm{AlCl}_{3} \bullet 6 \mathrm{H}_{2} \mathrm{O}$} & 1 & 54,3 \\
\hline & 2 & 75,0 \\
\hline & 3 & 79,8 \\
\hline & 4 & 86,8 \\
\hline & 5 & 76,0 \\
\hline & 6 & 62,8 \\
\hline
\end{tabular}

It was established that in addition to the main product the catalysate has contained a significant amount of the initial substance-lactic acid. Its separation, cleaning and re-introduction to the reaction has increased the overall yield of the product. A further increasing duration of the reaction adversely affects on yield of vinyl ester. The optimal conditions for the process are: reaction time 4 hours; catalyst $\mathrm{AlCl}_{3} \bullet 6 \mathrm{H}_{2} \mathrm{O}$ and at this the yield of vinyl ester was $86.8 \%$.

\section{CONCLUSION AND FUTURE WORK}

Vinylation of 2-hydroxypropanoic acid (lactic acid) with acetylene in the presence of zinc acetate catalysts and metal chlorides: zinc, chromium, iron (III) and aluminum has been investigated. It was found the optimal conditions for the synthesis of vinyl ester of lactic acid are: the reaction time 4 hours, the catalystzinc acetate and $\mathrm{AlCl}_{3} \cdot 6 \mathrm{H}_{2} \mathrm{O}$. The yield of the resulting vinyl ester was $87 \%$.

\section{REFERENCES}

1. Parmanov A.B., Nurmanov S.E., Tomash Maniecki, Ziyadullayev O.E., Abdullayev J.U. Homogeneous vinylation of 2-hydroxy-2 phenylethanical acid. International Journal of Research - Granthaalayah, India 6(11), 350-354. (2018).
2. Parmanov
A.B.,
Nurmanov
S.E., Phayzullaeva M.Ph., Abdullaev J.U., Soliev M.I. Synthesis of vinyl esters of some carbonic acids. // Austrian journal technical and natural science. 2017. № 1-2. p. 129-132. 
3. Ruihang Jiang, Zhangpei Chen, Kun Zhan. Tetrahedron Letters 59 (2018) 3279-3282.

4. J. Esquivias, R. G. Arrayar s, J. C. Carretero, J. Am. Chem. Soc. 2007, 129, 1480. 3059.

5. J. J. Kim, H. Alper, Chem. Commun. 2005,

6. Natekar, R.S.; Samant, S.D. Studies in the Friedel-Crafts reaction: part VI. Synthesis and intraand intermolecular Friedel-Crafts reaction of 2-methyl- 4-phenylpentanedioic anhydride. Indian J. Chem. Sect. B. 2002, 41B, 187-190.

7. F. Luo, C. Pan, P. Qian, J. Cheng. Carboxylic acids as substrates in homogeneous catalysis. Synthesis 2010, 2005.

8. Rathin Datta, Shih-Perng Tsai, Patrick Bonsignore, Seung-Hyeon Moon, James R. Frank. Technological and economic potential of poly (lactic acid) and lactic acid derivatives. ELSEVIER. FEMS Microbiology Reviews 16 (1995) 221-231.

УДК 547.56.564

СИНТЕЗ ЭТИЛЕН КАРБОНАТА РЕАКЦИЕЙ УГЛЕКИСЛОГО ГАЗА С ОКИСЬЮ ЭТИЛЕНА В ПРИСУТСТВИИ НОВЫХ ЦИНК МЕТИЛЕН-БИС-АЛКИЛФЕНОЛЯТНЫХ КАТАЛИЗАТОРОВ

\section{АННОТАЦИЯ}

Насирли Эмин Физули огль

Институт Нефтехимических Прочессов Наџиональной Академии Наук Азербайджана,

DOI: $10.31618 /$ ESU.2413-9335.2019.2.64.226

Синтезированы новые метилен-бис-алкилфеноляты цинка и показана их высокие устойчивость, каталитическая активность и производительность в синтезе циклических карбонатов, исходя из окиси этилена и СО2. Установлено, что без применения сокатализатора, синтезированные метилен-бисалкилфеноляты цинка при 25-120оС и давлении СО2 0.1-10.0 МПа за 30-180 мин приводят к образованию этилен карбоната с конверсией окиси этилена 40.0-100.0 \%, производительностью катализатора 34.8-414.5 г ЭК/г Кат и ТОF=150.1-2071.3 [моль ОЭ]/[моль Кат·ч], соответственно, и с селективностью по ЭК - 98$100 \%$

\section{ABSTRACT}

The new methylene-bis-alkyl-phenolates of zinc were synthesized and their high stability, catalytic activity, and productivity in the synthesis of cyclic carbonates starting from ethylene oxide and $\mathrm{CO} 2$ were established. It was found that without the use of cocatalyst, the synthesized methylene-bis- alkyl-phenolates of zinc at 25-120 $\mathrm{C}$ and a CO2 pressure of 0.1-10.0 MPa in 30-180 min lead to the formation of ethylene carbonate with an ethylene oxide conversion of 40.0-100.0\%, with a catalyst productivity of 34.8-414.5 g EC/g Cat and TOF=150.1-2071.3 $[\mathrm{mol} \mathrm{OE}] /[\mathrm{mol} \mathrm{Cat} \bullet \mathrm{h}]$, respectively, and with selectivity for EC $-98-100 \%$

Ключевые слова: окись этилена, двуокись углерода, метилен-бис-алкилфеноляты цинка, циклоприсоединение, этилен карбонат

Keywords: ethylene oxide, carbon dioxide, zinc methylene bis alkyl phenolates, cycloaddition, ethylene carbonate

\section{1. ВВЕДЕНИЕ}

Человечество использует природные ископаемые как источники энергии и огромное количество вырабатывается за счет сжигания нефти, газа и каменного угля. Естественным побочным продуктом их сжигания является диоксид углерода - парниковый газ, который негативно влияет на климат нашей планеты. С каждым днем становится более острой проблема утилизации $\mathrm{CO}_{2}$. В то же время в промышленности перерабатывается всего около 100 млн.тонн диоксида углерода, что составляет меньше $0,5 \%$ от всего объѐма выбросов $[2,14]$.

Вовлечение $\mathrm{CO}_{2}$ в химические реакции и синтез различных производных карбоновых кислот, лактонов, поликарбонатов и циклических карбонатов является одним из основных вариантов его утилизации [5]. Среди них циклические карбонаты особенно интересны в связи с их применением в качестве электролитов для литийионных батарей, а также промежуточных соединений для синтеза различных химических соединений полимеров [2, 3].
Для реакции $\mathrm{CO}_{2}$ с эпоксидами, в основном, используют кислоты Льюиса или Бренстеда. В большинстве случаев скорость реакции резко возрастает в присутствии нуклеофильных добавок - сокатализаторов, таких как амины, галогениданионы и т.п. Сегодня в распоряжении химиков имеется значительное количество каталитических систем, используемых в синтезе циклических карбонатов. Почти все каталитические системы, используемые в настоящее время для синтеза циклических карбонатов, можно отнести к одной из двух больших групп: в первую входят металлокатализаторы, то есть соли или комплексы металлов; вторую составляют органокатализаторы, в качестве которых чаще всего используются фосфониевые и аммониевые соли, а также спирты и фенолы. Большинство известных катализаторов имеет существенные недостатки, среди которых выделяются низкая устойчивость или активность, необходимость использования сокатализатора, высокая стоимость [8].

Поэтому, поиск и разработка принципиально новых, дешѐвых и «зелёных» каталитических 